\title{
Impact of Mobile Phone usage on Academic Performance and Behaviour of Medical Students
}

\author{
Nipunjot Grewal*, Jagminder Kaur Bajaj and Megha Sood \\ Department of Pharmacology, Punjab Institute of Medical Sciences, Jalandhar - 144006, Punjab, \\ India; dr_ngrewal@yahoo.co.in, jagminderbajaj@gmail.com, msood11@gmail.com
}

\begin{abstract}
Background: Mobile phone culture has brought about a revolution in technology and people of all age groups (especially youngsters) have become greatly dependant on mobiles for various reasons. It has become an integral part of routine work of students who rely on mobiles for academic purposes also. This study was planned to evaluate the impact of mobile phone use on health and academic performance of MBBS students. Methods: It was cross sectional questionnaire based study in which 300 MBBS students were involved. Various questions regarding mobile usage, associated benefits and problems pertaining to academic activities and impact on health were filled and tabulated in ranges and percentages. Results: All the students involved in study used mobile phones and their usage ranged from 0.2-6.5 hrs on a working day and0.5-8 hrs on holiday. Many students reported increased academic performance with the help of mobiles whereas few students reported disturbance in class, impaired concentration and increased use of abbreviations in routine. Also, students reported certain health issues like changes in vision, pain in wrist, neck and preference to stay alone with use of mobile phones. Conclusions: Excessive use of mobile phones can have deleterious effects on human mind and brain. Plethora of physical, psychological and behavioural problems can be seen with long term use of handsets. With advancements in technologies, associated risks are also bound to increase. So judicious and wise use of mobiles is a must to avoid harmful consequences in youngsters especially students.
\end{abstract}

Keywords: Academics, Health, Impact, Mobile

\section{Introduction}

Mobile Phone Culture is most widely spreading in the present era. It has become an essential part of modern life and is playing a vital role in decreasing distance and increasing communication among people. This small device has done that work which was not even accomplished by great leaders and even wonderful inventions. For 2019, the number of mobile phone users is forecast to reach 4.68 billion worldwide ${ }^{[1]}$ out of which 800 million people will be from India ${ }^{[2]}$. Mobile phone has affected almost every field of life but its effects on students learning especially at college level are deep and are multidimensional. With the passage of time, the darker side of technology is also revealed. Mobile devices have both positive and negative effects on human health and behaviour.
Some positive and healthy impacts and effects of mobile phone on students performance include the ease to contact their teachers, classmates and parents. They can use internet to search out the useful information and use the mobile as minicomputer. Besides using mobile phones for calling and texting, it has become a mode of relaxation for them. Many students use social networking sites and play games to take a break from their routine. At times, Youngsters prefer to carry two phones with them and they easily manage to handle their both activities of playing and communicating with their second phone at one time.

According to Ansari ${ }^{[3]}$ it has a number of negative and unhealthy impacts and effects on students performances at the university level, including the wastage of time and money. Its vibration and use may be harmful for health.

*Author for correspondence 
According to Awaz ${ }^{[4]}$, Sir William Stewart in his book "Mobile Phones and Base Stations" narrated that exposure of radio frequency causes great absorption of energy in the tissues of head which is harmful for nervous system. Vibration of mobile phone also has effects on the pumping of blood. Heat of mobile phone also causes skin problems.

Aoki and Downes ${ }^{[5]}$ conducted a research on students in United States. They proposed that majority of the students give preference to make calls at night. This can cause restlessness, sleep loss and other adverse outcomes. $\mathrm{Niaz}^{[6]}$ proposed that addictive mobile use has now become an addictive public health problem and awareness about the dangers linked with extreme usage and addictive behaviours must be extended among youngsters. This study was planned to evaluate the extent of usage and its effect on behaviour and academic performance of medical students of our institute.

\section{Objectives}

To study the extent of usage/dependence of mobile phones and its effect on academic performance and behaviour of medical students.

\section{Materials and Methods}

It was a cross sectional non-randomised questionnaire based study conducted after taking Institutional ethics Committee approval. Total of 300 MBBS students from first and second professionals were involved in the study. Incompletely filled perform as were excluded from the study. Structured questionnaire filled by student's were tabulated and results were analysed using ranges and percentages.

\section{Results}

Mobile phones were being used by $100 \%$ of students since minimum of 1 month to maximum of 10 years. $90 \%$ students had internet connection on their handsets. The use of mobile phones varied on working days and holidays. On a working day students used mobiles for average of 1.8 hours (0.2-6.5 hrs) while on holidays, its usage extended to 3.2 hours (0.5-8 hrs). This indicated more time devoted to phones on a holiday (Figure 1). $76.5 \%$ students depended on mobiles for their academic activities out of which $61.5 \%$

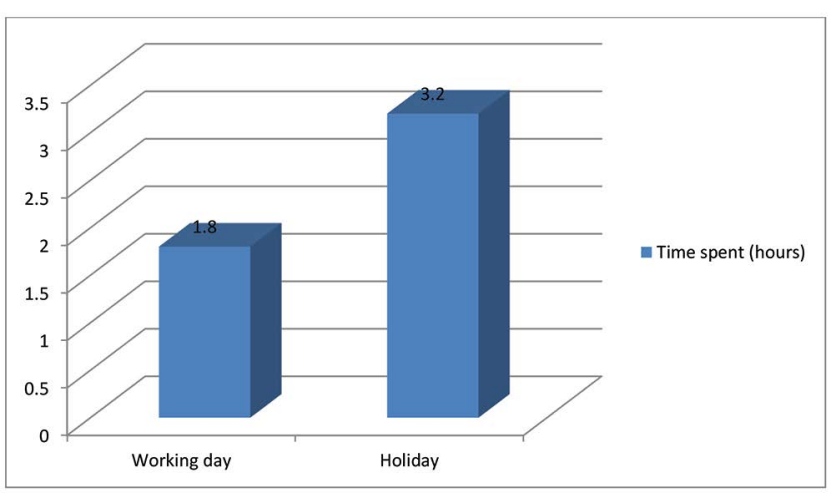

Figure 1. Time spent (hours).

reported improvement in academic performance (grades). But $28 \%$ students noticed increased use of abbreviations while writing exams that affected the scores in exams.

Also 32.5\% students reported impaired concentration in lectures due to use of handsets by their fellow friends (Figure 2).

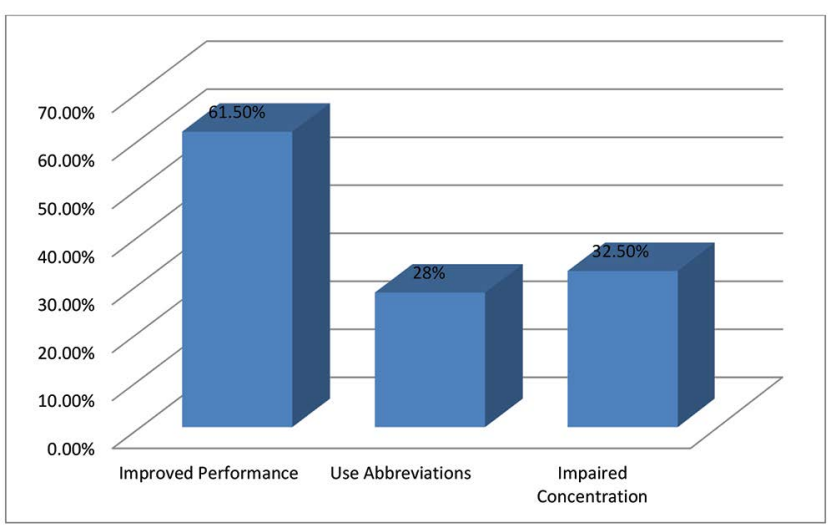

Figure 2. Impact of mobile use on academics.

It was observed that maximum time spent was 2-6 hours and was associated with significant improvement in academic activities $(\mathrm{p}=0.002)$ (Table 1$)$.

Changes in vision/eyesight were also reported by $25.5 \%$ students whereas orthopaedic problem (pain in neck, wrist) was noted in $15 \%$ students. With increase in number of hours spent on using mobile phones, changes in vision also increased significantly between two groups $(\mathrm{p}<0.001)$ (Table 2).

Orthopaedic problems also increased with increase in duration of mobile use. As the number of hours spent on mobile increased, orthopaedic problems in the form of wrist pain, pain in neck increased significantly (Table 3 ).

Behavioural problems were observed by $22 \%$ students. $15 \%$ of the study population felt less need for company of peer group/friends/family and preferred to stay alone (Figure 3). 
Table 1. Association of number of hours and improvement in academic performance

\begin{tabular}{|c|c|c|c|c|c|}
\hline \multicolumn{2}{|c|}{} & \multicolumn{2}{c|}{ improvement in academic performance } & Total \\
\cline { 3 - 6 } & & yes & $22(19.1 \%)$ & 43 \\
\hline Number of Hours & $<2 \mathrm{hrs}$ & Count & $21(11.4 \%)$ & $41(35.7 \%)$ & 145 \\
\hline & $2-6 \mathrm{hrs}$ & Count & $104(56.2 \%)$ & $52(45.2 \%)$ & 112 \\
\hline & $>6 \mathrm{hrs}$ & Count & $60(32.4 \%)$ & $\mathbf{1 1 5}$ & $\mathbf{3 0 0}$ \\
\hline & & Count & $\mathbf{1 8 5}$ & $\mathbf{1 1 5}$ & $\mathbf{3 0 0}$ \\
\hline
\end{tabular}

After applying pearson chi square, $\mathrm{p}=0.002$

Table 2. Association of number of hours and change in vision

\begin{tabular}{|c|c|c|c|c|c|}
\hline & & & \multicolumn{2}{|c|}{ Change in vision } & \multirow{2}{*}{ Total } \\
\hline & & & yes & No & \\
\hline \multirow[t]{3}{*}{ Number of Hours } & $<2 \mathrm{hrs}$ & Count & $8(9.9 \%)$ & $36(16.4 \%)$ & 44 \\
\hline & $2-6 \mathrm{hrs}$ & Count & $21(25.9 \%)$ & $114(52.1 \%)$ & 135 \\
\hline & $>6 \mathrm{hrs}$ & Count & $52(64.2 \%)$ & $69(31.5 \%)$ & 121 \\
\hline Total & & Count & 81 & 219 & 300 \\
\hline
\end{tabular}

Chi square test, $\mathrm{p}=0.0$

Table 3. Association of number of hours and orthopedic problems

\begin{tabular}{|c|c|c|c|c|c|}
\hline \multicolumn{2}{|c|}{} & \multicolumn{2}{c|}{ Orthopaedic problems } & \multicolumn{2}{c|}{ Notal } \\
\cline { 3 - 6 } & & yes & $37(14.7 \%)$ & 38 \\
\hline Number of Hours & $<2 \mathrm{hrs}$ & Count & $1(2.0 \%)$ & $126(50.2 \%)$ & 147 \\
\hline & $2-6 \mathrm{hrs}$ & Count & $21(42.9 \%)$ & $88(35.1 \%)$ & $\mathbf{2 5 1}$ \\
\hline Total & $>6 \mathrm{hrs}$ & Count & $27(55.1 \%)$ & $\mathbf{3 0 0}$ \\
\hline
\end{tabular}

Chi square test, $\mathrm{p}=0.007$

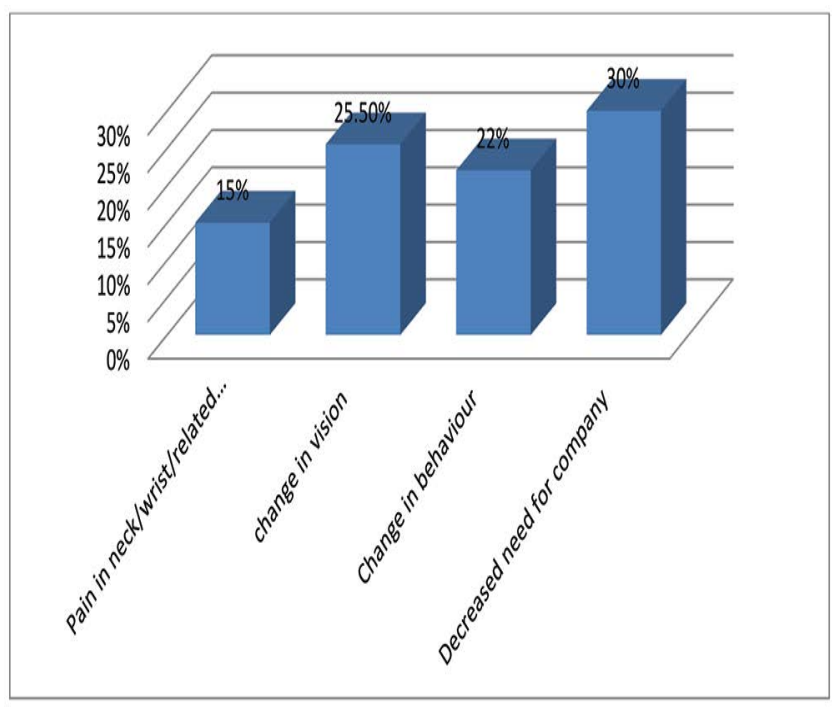

Figure 3. Impact of mobile use on health.
However, change in behaviour was not significant with increase in duration of mobile use. ( $p>0.05)$ (Table 4).

\section{Discussion}

The results showed average mobile usage of 1.8 hours and 3.2 hours on working day and holiday respectively which is in concordance with results of study ${ }^{[7]}$. It identified usage rate of 1.5-5 hours per day. Majority of mobiles were internet enabled which was similar to present study in which $90 \%$ students had internet connections on their handsets ${ }^{[8]}$. Many studies have revealed that students frequently report using a variety of electronic media including cell phones while in class, studying, and doing homework ${ }^{[9]}$. This finding is in concordance with 
Table 4. Association of number of hours and change in behaviour

\begin{tabular}{|c|c|c|c|c|c|}
\hline \multicolumn{2}{|c|}{} & \multicolumn{2}{c|}{ Orthopaedic problems } & \multirow{2}{*}{ Total } \\
\cline { 4 - 6 } \multicolumn{2}{|c|}{} & yes & No & \\
\hline Number of Hours & $<2 \mathrm{hrs}$ & Count & $7(9.6 \%)$ & $35(15.4 \%)$ & 42 \\
\hline & $2-6 \mathrm{hrs}$ & Count & $28(38.4 \%)$ & $80(35.2 \%)$ & 108 \\
\hline & $>6 \mathrm{hrs}$ & Count & $38(52.1 \%)$ & $112(49.3 \%)$ & 150 \\
\hline Total & & Count & $\mathbf{7 3}$ & $\mathbf{2 2 7}$ & $\mathbf{3 0 0}$ \\
\hline
\end{tabular}

Chi square test, $\mathrm{p}=0.456$

our study where $76.5 \%$ students used their handsets for academic purposes.

In another study conducted ${ }^{[10]}$ Majority of respondents reported that the frequent use of mobile phone sometimes interfered their learning whereas many were of the agreement that it also helped them in learning sometimes. However, about $75 \%$ of the respondents were of the opinion that the calls/messages received just before class impact on their ability to concentrate and $5.8 \%$ said it happens to them always. Also, $36.9 \%$ said that the usage of mobile during their study time distract them sometimes and approximately $83 \%$ said it also assists them in learning. In our study, there were $61.5 \%$ students who reported significant improvement in academic performance. However, $28 \%$ students noticed increased use of abbreviations while writing exams and $32.5 \%$ reported impaired concentration in lectures due to use of handsets.

Changes in vision/eyesight were also reported by $25.5 \%$ students whereas orthopaedic problem (pain in neck, wrist) was noted in $15 \%$ students. Behavioural problems like aggression, loneliness were observed by $22 \%$ students. $15 \%$ of the study population felt less need for company of peer group/friends/family and preferred to stay alone. In a study conducted by Acharya et al. various psychological issues were observed in college going students. Irritability was seen in $50.8 \%$ students and $38.5 \%$ of study population suffered from anxiety. Also 20.6\% respondents confirmed about lack of affection from friends and parents ${ }^{[11]}$.

Though in our study no significant change in behaviour was observed among students, it could possibly be related to more number of hours for long duration of time that affects the behaviour.

According to Ansari ${ }^{[3]}$ it has a number of negative and unhealthy impacts and effects on students' performances at the university level, including the wastage of time and money. Its vibration and use may be harmful for health.
A study by James and Drennan also highlights the financial costs, emotional stress, damaged relationships and falling literacy as adverse consequences of excessive usage. Also Walsh et al., found that people check their mobile phones regularly for missed calls and messages and keep their phones in close proximity without actually using their phones ${ }^{[7]}$.

\section{Conclusion}

Usage of mobile beyond a limit can have deleterious effects on human mind and brain. Extensive dependence on mobile phones and use of social media is increasing alarmingly. Multiple behavioural and psychological issues have already come up due to its prolonged use. Sincere efforts need to be taken by parents, mentors and society as a whole to curb excessive usage so as to get maximum advantage while minimize its harmful effects both on body and brain.

\section{Declarations}

Funding: No

Conflict of interest: No

Ethical approval: Yes

\section{References}

1. Number of mobile phone users worldwide from 2015-2020 (in billions). Accessed on 12 May 2017. Available at https:// www.statista.com/statistics/274774/forecast-of-mobilephone-users-worldwide/.

2. Number of mobile phone users in India from 2013-2019 (in millions). Accessed on 12 May 2017. Available at http:// www.statistics.com/statistics/274658/forecast-of-mobilephone-users-in-India. 
3. Ansari R. Harms of mobile phone. In: Afkar-i-Mualim May 2007. Lahore: Tanzeem-i-asatiza.

4. Javid M, Malik MA, Gujjar AA. Mobile phone culture and its psychological impact on students learning at university level. Language in India, Strength for Today and Bright Hope for Tomorrow. 2011; 11:415-22.

5. Aoki K, Downes EJ. An analysis of young people's use of and attitudes towards cell phones. Telematics and Informatics. 2003; 2:349-64. https://doi.org/10.1016/ S0736-5853(03)00018-2.

6. Niaz U. Addiction with Internet and Mobile: An overview. J. Pakistan Psychiatric Soc. 2008; 5(2):72.

7. Krithika M, Vasantha S. The mobile phone usage among teens and young adults impact of invading technology.
International Journal of Innovative Research in Science, Engineering and Technology. 2013; 2(12):7259-65.

8. World Scientific News. 118(2019):164-80.

9. Jacobsen WC, Forste R. The wired generation: Academic and social outcomes of electronic media use among university students. Cyberpsychology, Behavior, and Social Networking. 2011; 14:275-280.

10. Hossain MM. Impact of mobile phone usage on Academic performance. World Scientific News. 118(2019):164-80.

11. Acharya J, Acharya I, Wahgrey D. A study on some of common health effects of cell phone amongst college students. Journal of Community Medicine and Health Education 2013; 13(4):1-3. https://doi.org/10.4172/21610711.1000214 .

How to cite this article: Grewal N., Bajaj J.K. and Sood M. Impact of Mobile Phone usage on Academic Performance and Behaviour of Medical Students. Int. J. Med. Dent. Sci. 2020; 9(1): 1841-1845. 